\title{
Deep-sea litter in the Gulf of Cadiz (Northeastern
}

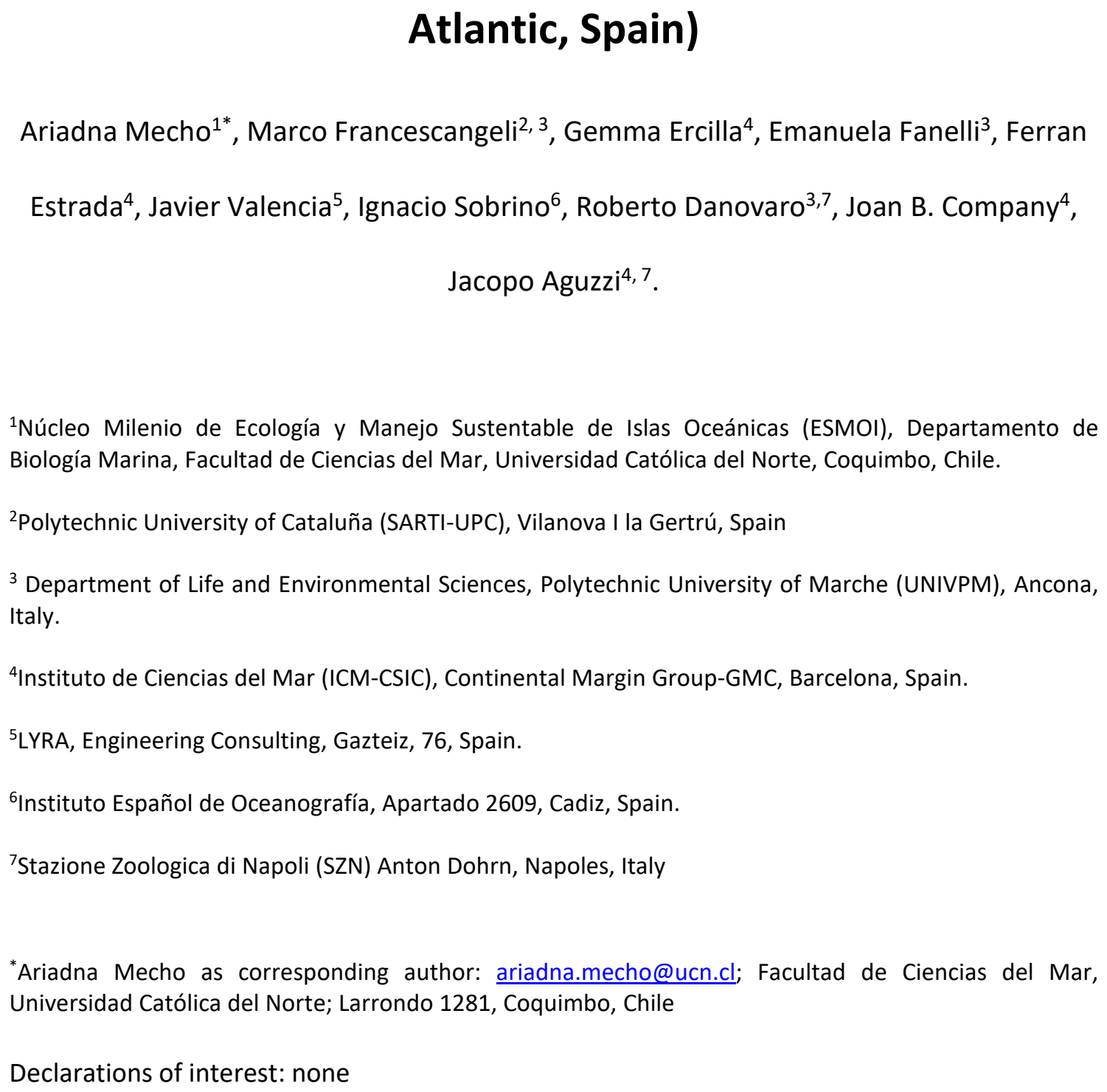


- Presence of diversified litter typology was observed at almost all monitored sites

- Higher presence of litter occurred in areas with fishing and maritime routes

- Higher presence of plastic occurred where bottom current intensity was lower

- Observed interactions occurred between fauna and litter

ABSTRACT

This study describes the distribution and composition of litter from the Gulf of Cadiz (Northeastern Atlantic, Spain), a region of confluence between the Atlantic and Mediterranean, with intense maritime traffic. Several geological features, such as canyons, open slopes and contourite furrows and channels, were surveyed by remotely operated vehicle (ROV) observations between depths of 220 and $1000 \mathrm{~m}$. Marine litter was quantified by grouping the observations into six categories. Our results indicate the presence of markedly different habitats in which a complex collection of different types of litter accumulate in relation to bottom current flows and maritime and fishing routes. This result justifies a seascape approach in further anthropogenic impact studies within deep-sea areas. litter

49 


\section{Introduction}

The Gulf of Cadiz $(\mathrm{GoC})$ is an area of confluence between the Atlantic and the Mediterranean with high maritime traffic. Here, the impact of littering in the form of waste from boats as well as commercial fishery artifacts discarded from the intense extracting activity has not yet been quantified (Coll et al., 2014).

The United Nations Environment Programme (UNEP) defines marine litter as any persistent, manufactured or processed solid material disposed of or abandoned in the marine environment (Chen, 2015). Litter accumulation depends on direct human activity at sea, such as commercial shipping (Ramirez-Llodra et al., 2013) and leisure crafts (Bergmann and Klages, 2012), combined with dispersive oceanographic and hydrographic processes (Galgani et al., 1996), as well as off-land transportation (Mecho et al., 2017). To date, litter has been found in all marine habitats, from the sea surface down to the deepest sea bottoms (Miyake et al., 2011; Peng et al., 2019), with a trend of degradation time decreasing over depth (Barnes et al., 2009). Nevertheless, litter impacts on marine ecosystems are still largely underestimated. For example, the abundance and impact of a certain type of litter on marine ecosystems at all depths is hard to quantify due to the presence of small pieces (Ramirez-Llodra et al., 2010) and microplastics (Ory et al., 2018). The dumping of toxic artifacts is an additional source of underestimated impacts. Ammunitions and other military materials can release chemical pollutants due to the corrosive effect of seawater on iron or lead shells (Amato et al., 2006); therefore, a study and report of the distribution of these types of toxic litter are highly recommended.

Several studies on sessile fauna have been undertaken to explore the biodiversity in different areas of the GoC (Delgado et al., 2013), revealing the occurrence of several sensitive and vulnerable habitats within the area, including cold-water corals or crinoid beds (Fonseca et al., 2014). However, to date, no quantitative investigation of the typology or abundance of litter artifacts or assessment of the impact of this phenomenon on deep-sea ecosystems have been undertaken in the GoC within the context of the specific oceanographic and marine traffic conditions in the area. The aim of this study is therefore to obtain new 
insights into the typology, abundance and distribution of litter artifacts occurring in the different deep-sea habitats of $\mathrm{GoC}$, evaluate their potential interactions with local megafauna and determine how this is affected by the interplay between the morpho-sedimentary environment and anthropogenic activity.

\section{Study area}

The $\mathrm{GoC}$ is an area of complex morphology due to the interaction between structural and contourite features formed under the action of Mediterranean Overflow Water (MOW) bottom currents. The physiography of this area results from a complex geodynamic evolution associated with the interaction between the African and Eurasian tectonic plates (Maldonado and Nelson, 1999). The shelf break is located at a depth of approximately 120-140 m, and the continental slope extends down to approximately $4300 \mathrm{~m}$. The along-slope abraded surface ( $100 \mathrm{~km}$ long and $\sim 30 \mathrm{~km}$ wide) contains two large channels (upper at depths of $\sim 550-620 \mathrm{~m}$ and lower at depths of $\sim 660-750 \mathrm{~m}$ ) associated with sedimentary drifts and erosive furrows. Irregular submarine canyons and unstable sedimentary deposits are downslope features that locally interrupt the along-slope trend in the contourites (see Fig. 1).

The GoC region is also of great oceanographic interest. The most studied hydrographic feature is the overflow of Mediterranean waters, which mix and accelerate through the Strait of Gibraltar and cascade down the GoC continental slope, forming the MOW (Fig. 1A). The MOW flows northwestward paralleling the continental slope, and its bottom layer sweeps the seafloor between 400 and 1400 m depth (Nelson et al., 1993). In the proximal domains, MOW velocities, after overflow of the Mediterranean waters, range from $0.3 \mathrm{~m} / \mathrm{s}$, increasing southward, to approx. $1.2 \mathrm{~m} / \mathrm{s}$ (Sánchez-Leal et al., 2014) (Fig.1B). These values decrease progressively northwestward (approximately $0.4 \mathrm{~m} / \mathrm{s}$ ), although local bottom current increases $(0.5 \mathrm{~m} / \mathrm{s})$ may occur when MOWs interact with seafloor obstacles (García et al., 2016) (Fig.1B).

\section{Materials and Methods}




\subsection{ROV video surveys}

An Argus work-class remotely operated vehicle (ROV) was used during September 2014 aboard the R/V Sarmiento de Gamboa. Video transects were carried out with a frontal color camera (Sony FCBH10 Argus RS Focus Zoom HDTV) under four Halogen 250 W DSPL lights. Navigation settings during video transecting followed standard protocols (Ayma et al., 2016) with the ROV positioned at $\sim 1-1.5 \mathrm{~m}$ above the bottom, moving at a constant speed of 1.0 knots.

A total of 17 dives adding more than 50 hours of video footage covering an approximate depth range between 200 and $1000 \mathrm{~m}$ took place in different sedimentary environments (Fig.1C) following the Hernández-Molina et al. (2014) classification: nine dives were recorded on contouritic furrow domains, five dives occurred in contouritic channels, two dives occurred on the open uppermost slope, and finally, one dive occurred on an upper slope canyon. The number of dives and associated oceanographic data plus navigation metadata are presented in Table 1 for each surveyed area. Depth and current data were averaged and then georeferenced in relation to our video transects with the help of Global Mapper and QGIS software.

The video-swept seabed surface was calculated per dive (Table 1) through laser calibration by measuring each transect length with a global mapper. Then, the length was multiplied by the field of view width to derive the area. The scaling of the imaged seabed area was precisely calculated by using two parallel laser beams (50 cm apart) mounted above the camera. For the laser calibration, a grid was deployed on a flat seabed area by the ROV arm, and laser beams were aligned with its mesh corners. The laser point distance was $50 \mathrm{~cm}$ at an approximate navigation height of $\sim 100-150 \mathrm{~cm}$, resulting in an estimated field of view width of $1.5 \mathrm{~m}$.

\subsection{Litter estimation and data analysis}

Litter was classified according to the available literature (Galgani et al., 2000; Pham et al., 2014; Ramirez-Llodra et al., 2011) as ceramic (i.e., amphorae fragments), plastic, glass, metal, abandoned longlines and fishing nets (Fig. 2A-F). The abundances of the different types of litter were estimated in each morpho-sedimentary domain by dividing counted items per unit of video-swept area, standardized to $\mathrm{km}^{2}$ (Mecho et al., 2017). A relative percentage of litter presence per type was then quantified per transect 
and then represented per domain. For each dive, we then related litter distributions with sedimentary and oceanographic environmental data (see below) to provide some indication of the environmental control of their distributions. Finally, we georeferenced our litter data and represented their presence along marine traffic routes (Junta de Andalucía, 2011) to verify the potential footprint of commercial navigation in deep-sea ecosystems in terms of historic dumping.

We also considered trawling impact as a proxy of the fishing activity footprint, estimated by considering each trawl mark crossing the camera field of view as one record. For those trawl marks included for a longer time (i.e., whose axis partially coincided with the dive trajectory), one record each minute of continuous video observation was scored. Considering that trawl marks are estimated as a proxy and are not artifacts, we discuss their presence separately from the litter. To determine the trawled area by the Spanish Fishing Fleet, we followed Global Fishing Watch (https://globalfishingwatch.org/), a web page using the blue box located on ships, to visualize the approximate ship locations (with the exact tracking data being private, these are the best available data) and determine global fishing activity. The vessel monitoring system (VMS) reported by the Spanish Government Annual Report on the Activity of the Spanish Fishing Fleet reports 125 bottom-trawl vessels fishing in the GoC.

Additionally, we also provided clinker-like observations (Fig. 2E; Appendix 1). The clinker is a general name used for different anthropological debris (i.e., burned charcoal from steamboats). Considering that this type of debris has not been produced for more than a century, we only describe the presence of this debris type, but we do not consider the items modern litter items.

\section{Results}

\subsection{Litter abundance and distribution}

The overall abundances per litter category are reported in Fig. 3A. A diversified set of litter items was detected in all morpho-sedimentary domains, the relative abundance of which is reported in Table 2. Metal and plastic were commonly observed, representing $34 \%$ and $33 \%$, respectively, of the total litter observations (Fig. 
$3 A)$. These types were followed by glass artifacts (representing $20 \%$ ), fishing nets (6\%), ceramic items (5\%) and longlines (2\%). A total of 224 clinker-like observations were reported (Fig. 2E; Appendix 1).

In the contouritic furrow domain, most of the detected litter was metal debris, representing $23 \%$ (see Fig. $3 \mathrm{~B}$ ) of the total observations, followed by plastic items (22\%), ceramic (ancient manufactured amphorae) and fishing nets (17\% each). The presence of lost longlines, such as wires entangled with sponges in dives no. 3 (at depths of $\sim 653-651 \mathrm{~m}$ ) and 6 (at depths of $\sim 623-613 \mathrm{~m}$ ), was also noted (12\%). Finally, glass items represented only $9 \%$ of the litter.

In the contouritic channels, glass dominated the litter observations (i.e., 48\%, see Fig. 3C). In comparison, relatively lower percentages of plastic (23\%) and metal (21\%) artifacts were detected. Large ghost trawl-fishing nets were detected at a low percentage (8\%). One of these trawl nets was surrounded by coral rubble, suggesting trawling activity over a cold-water coral reef of Madrepora oculata. Few trawling marks were observed on the contouritic areas (four annotations during dive no. 16 at $\sim 669 \mathrm{~m}$ ). The presence of buried intercontinental telecommunication cables during dive no. 8 at a depth of $\sim 640 \mathrm{~m}$ was also detected.

On the upper open slope, the highest percentage of litter was represented by plastic $(54 \%)$, followed by metal ( $24 \%$, see Fig. 3D). Fewer percentages of ceramic (17\%) and glass (5\%) were observed. Ceramic was represented by ancient manufactured amphorae (see Fig. 2A). In this zone, we did not observe the presence of trawling impacts (marks and fishing items) or longlines.

Finally, in the upper slope canyon, in comparison to the other litter types, metallic litter was present in a higher percentage, representing more than half of the total observations in the area (55\%), followed by plastic (43\%) and glass (2\%) (Fig. 3E). Military dumping sites that contain grenades and metal projectiles were also reported in the area (see Fig. 2F). Several trawl marks were observed on the contouritic channel and upper slope canyon (i.e., 50 annotations - dives 16-17), but ghost fishing nets were not observed.

\subsection{Species interaction with litter and traffic distribution}


Several species of fishes and decapod crustaceans were observed to interact with litter artifacts (Fig. 4). At a depth of $\sim 520 \mathrm{~m}$, two specimens of the fish Phycis blennoides were observed hiding under an unidentified metal object and in a plastic tube, and the decapod Munida sp. was also observed hiding under a metal projectile (dive no. 17; Fig. 4A). The crab Bathynectes maravigna was observed hiding by a metal artifact at a depth of $663 \mathrm{~m}$ (dive no. 16; Fig. 4B). Deeper, at $\sim 895 \mathrm{~m}$, the shrimp Plesionika martia was observed sheltering under a plastic sheet, and two unclassified individuals of the family Pandalidae (probably P. martia) were hidden in a plastic bag (dive nos. 16 and 18).

The interaction of low motility or sessile species on litter artifacts was also reported. The crinoid Leptometra celtica and some unclassified anthozoans were in contact with a long piece of metal at depths of 737 and $654 \mathrm{~m}$ (dive nos. 15 and 16, respectively) (Fig. 4C). A specimen of the sponge Pachastrella monilifera was observed entangled with a lost fishing net at $654 \mathrm{~m}$ (dive no. 3). Two other individuals of $P$. monilifera were identified intertwined with a longline in dive no. 6 at depths of $628 \mathrm{~m}$ and $613 \mathrm{~m}$. Many sea urchins (Cidaris cidaris) were observed on or near litter artifacts in dives nos. 16, 15 and 6, in a depth range of 617 to $743 \mathrm{~m}$ (Fig. 4D). Some tubeworms m. exposed the clinker-like debris to the surface via sediment resuspension.

\section{Discussion}


This study quantifies for the first time the litter observed on the deep-sea bottoms in the Gulf of Cadiz. We reported the presence of a diversified typology of litter items in almost all video-inspected geomorphologies. Similarly, the interaction between litter and local megafauna is discussed.

Plastic, metal, and glass artifacts are commonly found in the Mediterranean Sea (Mecho et al., 2017; Consoli et al., 2018 a, b) and NE Atlantic (Miyake et al., 2011). Here, we recorded the highest litter concentration in the area of the upper slope canyon and adjacent contouritic channel (Dives 17-16, respectively), which were also the locations of clinker debris. According to Global Fishing Watch (https://globalfishingwatch.org/), the trawling activity in our study area appeared concentrated in the flat muddy grounds near the canyon mouth. Then, we considered in addition to the regular maritime traffic, the litter dumped from the fishing vessels, which is not considered on shipping route maps.

Submarine canyons are also known as litter collectors for their funnel action of land inputs (Mordecai et al., 2011; Pierdomenico et al., 2019). This has been reported in canyons whose heads are close to the coast (a few km) (Mecho et al., 2017). In the present study, the head of the surveyed canyon is approximately $25 \mathrm{~km}$ from the coastline, and its head does not incise the continental shelf; thus, it is considered a blind canyon confined to the continental slope (Harris and Whiteway, 2011; Lo lacono et al., 2014). The sediment transport in the GoC continental shelf is affected by an important Atlantic inflow moving southwestwards (down to $600 \mathrm{~m}$ water depth, Lobo et al., 2000), and this inflow may favor the transport and funneling of litter with buoyancy properties (i.e., plastic) when this inflow interacts with the canyon head. This means that plastic could come not only from nearby sources but also from far away sources. When we overlapped our georeferenced data with bottom current flows, we also observed that litter is concentrated in the sites affected by relatively weaker bottom currents (Fig.5A). This would suggest that bottom current deceleration triggers or favors deposition of this type of litter. In fact, in videos where bottom currents are relatively strong, the presence of floating plastics passing the ROV is common.

The mapped glass, metal and ceramic were probably found close to where they were dropped. This is because considering their size (a few tens of centimeters) and 
material density, bottom currents sweeping the area cannot transport them as a suspension load or bed load (Hjulström, 1935).

When we overlapped our georeferenced litter data with the routes of maritime traffic (Junta de Andalucía, 2011), we observed a match with the general presence of litter. Based on the above mentioned factors, we suggest that the presence of a high amount naval and recreational traffic and fishing activities are related to the presence and abundance of litter artifacts of all kinds.

The presence of metal, longlines, fishing nets and trawling marks are related to fishing activities, indicating that they are mainly concentrated in the upper slope canyon (trawling) and furrow (longline and middle water fishing) areas. This type of litter is commonly observed in deep-sea ROV imaging studies (Mecho et al., 2017; Vertino et al., 2010) and causes unpredicted impacts on seabed fauna (Consoli et al; 2018 a, b) through long-lasting (decomposition rate-dependent) ghost fishing (Ramirez-Llodra et al., 2013). We also observed discarded trawling net trapping litter, and these artifacts can indeed act as litter concentration sources (Mordecai et al., 2011). Because of the generally highly resistant plastic material of which such fishing equipment is made, ghost fishing and litter trapping effects will be persistent for an unpredictable time interval (Deroiné et al., 2019; Kim et al., 2016). Furthermore, the presence of discarded longlines was also detected. The Activity of the Spanish Fishing Fleet reported 657 vessels that fished in the GoC using artisanal methods (gillnets, hooks and traps) and 75 purse seiners. Several of these lost or discarded artifacts were observed entangled with sponges ( $P$. monilifera, a vulnerable marine ecosystems (VME) species indicator), representing an additional source of damage for benthic fauna, especially in areas where erect sessile organisms (e.g., sponges and corals) are abundant (Clark et al., 2007; Consoli et al; 2018 a).

Even if most of these litter items are considered a potential source of damage, several specimens of decapod crustaceans and fishes were observed in association with litter artifacts. The introduction of hard material increases habitat heterogeneity at a small scale (Bergmann and Klages, 2012). Megabenthos can use litter as a substitution for burrows for hiding (Ayma et al., 2016), indicating that these artifacts effectively enhance camouflage opportunities (Braga-Henriques et al., 2011). Ceramic (i.e., amphorae) in muddy slope areas can be used by animals not only for sheltering 
but also for enhancing predatory performance (e.g., Munida sp. observed as standing on an amphora as an elevated position to catch krill; Ayma et al., 2016). At the same time, ceramic and other hard substrates, such as clinker debris and ammunition, can be used for colonization by sessile organisms (Mecho et al., 2017; Neves et al., 2015). In fact, we observed species of Munida sp. using ammunition as shelter.

Similarly, we reported the presence of buried submarine telecommunication cables in a contouritic channel. In the Northeastern Atlantic, the maximum seabed surface coverage of submarine cables laying on the seabed has been estimated to be approximately $5-10 \mathrm{~km}^{2}$ (Carter et al., 2009). This is most likely an underestimation of cable impacts since the value does not take into account buried lines (Benn et al., 2010).

In this scenario, our data contribute the quantification of global litter impacts in our oceans. Litter dumping overlaps with the tracks of maritime traffic (Junta de Andalucía, 2011) and major marine currents. Thus, our data are relevant in that they provide new information at a time when international management and legal entities are seeking to quantify global litter impact in our oceans.

\section{Funding}

The present study was developed in the framework of the Tecnoterra (ICM-CSIC/UPC) Associate Unit and the following project activities, funded by the Spanish Government MOWER (CTM 2012-39599-C03), FAUCES (CTM2015-65461-C2-1-R) and RESBIO (TEC2017-87861-R), plus the ARIM (Autonomous Robotic sea-floor Infrastructure for benthopelagic Monitoring) funded by the MartTERA ERA-Net Cofound. Francescangeli M. was funded by the European Project ERASMUS grant 2017. Mecho A. was partially funded by the Pure Ocean Fund, managed by the King Baudouin Foundation.

\section{References}

Amato, E., Alcaro, L., Corsi, I., Della Torre, C., Farchi, C., Focardi, S., Marino, G., Tursi, A., 2006. An integrated ecotoxicological approach to assess the effects of pollutants released by unexploded chemical ordnance dumped in the southern Adriatic (Mediterranean Sea). Mar. Biol. 149, 17-23. https://doi.org/10.1007/s00227-005-0216-x

Ayma, A., Aguzzi, J., Canals, M., Lastras, G., Bahamón, N., Mecho, A., Company, J.B., 
2016. Behavioural observations of deep-water fauna in submarine canyons of the Northwestern Mediterranean Sea by ROV and Agassiz observations. Deep Sea Res. Part I Oceanogr. Res. Pap. 114, 149-159.

Barnes, D.K.A., Galgani, F., Thompson, R.C., Barlaz, M., 2009. Accumulation and fragmentation of plastic debris in global environments. Philos. Trans. R. Soc. B Biol. Sci. 364, 1985-1998. https://doi.org/10.1098/rstb.2008.0205

Benn, A.R., Weaver, P.P., Billet, D.S., Van Den Hove, S., Murdock, A.P., Doneghan, G.B., Le Bas, T., 2010. Human activities on the deep seafloor in the North East Atlantic: an assessment of spatial extent. PLoS One 5, e12730.

Bergmann, M., Klages, M., 2012. Increase of litter at the Arctic deep-sea observatory HAUSGARTEN. Mar. Pollut. Bull. 64, 2734-2741. https://doi.org/10.1016/j.marpolbul.2012.09.018

Braga-Henriques, A., Carreiro-Silva, M., Tempera, F., Porteiro, F.M., Jakobsen, K., Jakobsen, J., Albuquerque, M., Serrão Santos, R., 2011. Carrying behavior in the deep-sea crab Paromola cuvieri (Northeast Atlantic). Mar. Biodivers. 42, 37-46. https://doi.org/10.1007/s12526-011-0090-3

Carter, L., Burnett, D., Drew, S., Marle, G., Hagadorn, L., Bartlett-McNeil, D., Irvine, N., 2009. Submarine cables and the oceans: connecting the world. UNEP-WCMC Biodivers. Ser. 31.

Chen, C.L., 2015. Regulation and Management of Marine Litter, in: Bergmann, M., Klages, M., Gutow, L. (Eds.), Marine Anthropogenic Litter. Springer Open, pp. 395428. https://doi.org/10.1007/978-3-319-16510-3_15

Clark, M.R., Vinnichenko, V.I., Gordon, J.D., Beck-Bulat, G.Z., Kukharev, N.N., Kakora, A.F., 2007. Large-scale distant-water trawl fisheries on seamounts., in: Pitcher, T.J., Morato, T. (Eds.), Seamounts: Ecology, Fisheries, and Conservation. Blackwell Fisheries and Aquatic Resources Series. pp. 361-399.

Coll, M., Carreras, M., Ciércoles, C., Cornax, M.J., Gorelli, G., Morote, E., Sáez, R., 2014. Assessing fishing and marine biodiversity changes using fishers' perceptions: The Spanish Mediterranean and Gulf of Cadiz case study. PLoS One 9, e85670. https://doi.org/10.1371/journal.pone.0085670

Consoli, P., Andaloro, F., Altobelli, C., Battaglia, P., Campagnuolo, S., Canese, S., Castriota, L., Cillari, T., Falautano, M., Pedà, C., Perzia, P., Sinopoli, M., Vivona, P., Scotti, G., Esposito, V., Galgani, F., Romeo, T., 2018a. Marine litter in an EBSA (Ecologically or Biologically Significant Area) of the central Mediterranean Sea: Abundance, composition, impact on benthic species and basis for monitoring entanglement. Env. Pol. 236, 405-415.

Consoli, P., Falautano, M., Sinopoli, M., Perzia, P., Canese, S., Esposito, V., Battaglia, P., Romeo, T., Andaloro, F., Galgani, F., Castriota, L., 2018b. Composition and abundance of benthic marine litter in a coastal area of the central Mediterranean Sea. Mar. Pol. Bul. 136, 243-247.

Delgado, M., Rueda, J.L., Gil, J., Burgos, C., Sobrino, I., 2013. Spatial characterization of megabenthic epifauna of soft bottoms around mud volcanoes in the Gulf of Cádiz. J. Nat. Hist. 47, 1803-1831. 
Deroiné, M., Pillin, I., Le Maguer, G., Chauvel, M., Grohens, Y., 2019. Development of new generation fishing gear: A resistant and biodegradable monofilament. Polym. Test. 74, 163-169. https://doi.org/10.1016/j.polymertesting.2018.11.039

Fonseca, P., Abrantes, F., Aguilar, R., Campos, A., Cunha, M., Ferreira, D., Fonseca, T.P., García, S., Henriques, V., Machado, M., Mechó, A., Relvas, P., Rodrigues, C.F., Salgueiro, E., Vieira, R., Weetman, A., Castro, M., 2014. A deep-water crinoid Leptometra celtica bed off the Portuguese south coast. Mar. Biodivers. 44. https://doi.org/10.1007/s12526-013-0191-2

Galgani, F., Leaute, J.P., Moguedet, P., 2000. Litter on the sea floor along European coasts. Mar. Pollut. Bull. 40, 516-527. https://doi.org/10.1016/S0025326X(99)00234-9

Galgani, F., Souplet, A., Cadiou, Y., 1996. Accumulation of debris on the deep sea floor off the French Mediterranean coast. Mar. Ecol. Prog. Ser. 142, 225-234.

García, M., Hernández-Molina, F.J., Alonso, B., Vázquez, J.T., Ercilla, G., Llave, E., Casas, D., 2016. Erosive sub-circular depressions on the Guadalquivir Bank (Gulf of Cadiz): Interaction between bottom current, mass-wasting and tectonic processes. Mar. Geol. 378, 5-19.

Gasser, M., Pelegrí, J.L., Emelianov, M., Bruno, M., Grácia, E., Pastor, M., Peters, H., Rodríguez-Santana, Á., Salvador, J., Sánchez-Leal, R.F., 2017. Tracking the Mediterranean outflow in the Gulf of Cadiz. Prog. Oceanogr.

Harris, P.T., Whiteway, T., 2011. Global distribution of large submarine canyons: Geomorphic differences between active and passive continental margins. Mar. Geol. 285, 69-86. https://doi.org/10.1016/j.margeo.2011.05.008

Hernández-Molina, F.J., Llave, E., Preu, B., Ercilla, G., Fontan, A., Bruno, M., Serra, N., Gomiz, J.J., Brackenridge, R.E., Sierro, F.J., Stow, D.A.V., García, M., Juan, C., Sandoval, N., Arnaiz, A., 2014. Contourite processes associated with the Mediterranean Outflow Water after its exit from the Strait of Gibraltar: Global and conceptual implications. Geology 42, 227-230.

Hjulström, F., 1935. Studies of the Morphological Activity of Rivers as Illustrated by the River Fyris. Geol. Inst. Univ. Uppsala Bull. 25, 221-238. https://doi.org/10.2307/519824

Kim, S., Kim, P., Lim, J., An, H., Suuronen, P., 2016. Use of biodegradable driftnets to prevent ghost fishing: physical properties and fishing performance for yellow croaker. Anim. Conserv. 19, 309-319. https://doi.org/10.1111/acv.12256

Lobo, F.J., Hernández-Molina, F.J., Somoza, L., Rodero, J., Maldonado, A., Barnolas, A., 2000. Patterns of bottom current flow deduced from dune asymmetries over the Gulf of Cadiz shelf (southwest Spain). Mar. Geol. 164, 91-117. https://doi.org/10.1016/S0025-3227(99)00132-2

Lo lacono, C.L., Sulli, A., Agate, M., 2014. Submarine canyons of north-western Sicily (Southern Tyrrhenian Sea): Variability in morphology, sedimentary processes and evolution on a tectonically active margin. Deep Sea Res. Part II Top. Stud. Oceanogr. 104, 93-105. 
Maldonado, A., Nelson, C.H., 1999. Interaction of tectonic and depositional processes that control the evolution of the Iberian Gulf of Cadiz margin. Mar. Geol. 155, 217-242. https://doi.org/10.1016/S0025-3227(98)00148-0

Mecho, A., Aguzzi, J., De Mol, B., Lastras, G., Ramirez-Llodra, E., Bahamon, N., Company, J.B., Canals, M., 2017. Visual faunistic exploration of geomorphological human-impacted deep-sea areas of the north-western Mediterranean Sea. J. Mar. Biol. Assoc. United Kingdom 1-12. https://doi.org/10.1017/S0025315417000431

Miyake, H., Shibata, H., Furushima, Y., 2011. Deep-sea litter study using deep-sea observation tools. Mar. Environ. Model. Anal. 261-269.

Mordecai, G., Tyler, P.A., Masson, D.G., Huvenne, V.A.I., 2011. Litter in submarine canyons off the west coast of Portugal. Deep Sea Res. Part II Top. Stud. 58, 24892496.

Nelson, C.H., Baraza, J., Maldonaldo, A., 1993. Mediterranean Undercurrent Sandy Contourites, Gulf of Cadiz, Spain. Sediment. Geol. 82, 103-131.

Neves, D., Sobral, P., Pereira, T., 2015. Marine litter in bottom trawls off the Portuguese coast. Mar. Pollut. Bull. 99, 301-304. https://doi.org/10.1016/j.marpolbul.2015.07.044

Ory, N., Chagnon, C., Felix, F., Fernández, C., Ferreira, J.L., Gallardo, C., Garcés Ordóñez, O., Henostroza, A., Laaz, E., Mizraji, R., Mojica, H., Murillo Haro, V., Ossa Medina, L., Preciado, M., Sobral, P., Urbina, M.A., Thiel, M., 2018. Low prevalence of microplastic contamination in planktivorous fish species from the southeast Pacific Ocean. Mar. Pollut. Bull. 127, 211-216. https://doi.org/10.1016/j.marpolbul.2017.12.016

Peng, G., Bellerby, R., Zhang, F., Sun, X., Li, D., 2019. The ocean's ultimate trashcan: Hadal trenches as major depositories for plastic pollution. Water Res. 115121. https://doi.org/10.1016/j.watres.2019.115121

Pham, C.K., Ramirez-Llodra, E., Alt, C.H.S., Amaro, T., Bergmann, M., Canals, M., Company, J.B., Davies, J., Duineveld, G., Galgani, F., Howell, K.L., Huvenne, V.A.I., Isidro, E., Jones, D.O.B., Lastras, G., Morato, T., Gomes-Pereira, J.N., Purser, A., Stewart, H., Tojeira, I., Tubau, X., Van Rooij, D., Tyler, P.A., 2014. Marine litter distribution and density in European seas, from the shelves to deep basins. PLoS One 9, e95839. https://doi.org/10.1371/journal.pone.0095839

Pierdomenico, M., Casalbore, D., Chiocci, F.L., 2019. Massive benthic litter funnelled to deep sea by flash-flood generated hyperpycnal flows. Sci. Rep. 9. https://doi.org/10.1038/s41598-019-41816-8

Ramirez-Llodra, E., Brandt, A., Danovaro, R., De Mol, B., Escobar, E., German, C.R., Levin, L.A., Martinez Arbizu, P., Menot, L., Buhl-Mortensen, P., Narayanaswamy, B.E., Smith, C.R., Tittensor, D.P., Tyler, P.A., Vanreusel, A., Vecchione, M., 2010. Deep, diverse and definitely different: unique attributes of the world's largest ecosystem. Biogeosciences 7, 2851-2899. https://doi.org/10.5194/bg-7-28512010

Ramirez-Llodra, E., De Mol, B., Company, J.B., Coll, M., Sardà, F., 2013. Effects of natural and anthropogenic processes in the distribution of marine litter in the 
deep Mediterranean Sea. Prog. Oceanogr. 118, 273-287. https://doi.org/10.1016/j.pocean.2013.07.027

Ramirez-Llodra, E., Tyler, P.A., Baker, M.C., Bergstad, O.A., Clark, M.R., Escobar, E., Levin, L.A., Menot, L., Rowden, A.A., Smith, C.R., Van Dover, C.L., 2011. Man and the Last Great Wilderness: Human Impact on the Deep Sea. PLoS One 6, e22588. https://doi.org/10.1371/journal.pone.0022588

Sánchez-Leal, R., Bellanco-Esteban, M., Sanchez-Garrido, J., Ruiz-Villarreal, M., González-Pola, C., Sánchez-Leal, R., Bellanco-Esteban, M., Sanchez-Garrido, J., Ruiz-Villarreal, M., Gonzalez-Pola, C., 2014. What drives the spreading pattern of the Mediterranean Outflow Water (MOW) in the eastern Gulf of Cadiz, SW Iberian Peninsula? ICES J. Mar. Sci. 1, 3630.

Vertino, A., Savini, A., Rosso, A., Di Geronimo, I., Mastrototaro, F., Sanfilippo, R., Gay, G., Etiope, G., 2010. Benthic habitat characterization and distribution from two representative sites of the deep-water SML Coral Province (Mediterranean). Deep Sea Res. Part II Top. Stud. Oceanogr. 57, 380-396. https://doi.org/10.1016/j.dsr2.2009.08.023

Zitellini, N., Gràcia, E., Matias, L., Terrinha, P., Abreu, M.A., De Alteriis, G., Henriet, J.P., Dañobeitia, J.J., Masson, D.G., Mulder, T., Ramella, R., Somoza, L., Diez, S., 2009. The quest for the Africa-Eurasia plate boundary west of the Strait of Gibraltar. 
Table 1. Metadata specifying dives (No.), Geo: morpho-sedimentary domain (US: 492 Upper open slope; CC: Contouritic Channel), date, latitude, longitude, averaged depth $493(\mathrm{~m})$, video duration. The estimated video-inspected seabed surface $\left(\mathrm{km}^{2}\right)$ and bottom 494 current velocity $(\mathrm{m} / \mathrm{s})$ (from Gasser et al., 2017).

495

\begin{tabular}{|c|c|c|c|c|c|c|c|c|}
\hline Geo & No. & Date & Lat (N) & Long (W) & $\mathbf{m}$ & Duration & $\mathrm{km}^{2}$ & V \\
\hline US & 2 & 09/03/2014 & $36002.1931^{\prime}$ & 60 29.2622' & 222 & 03:45 & 0.0130 & 0.20 \\
\hline Furrow & 3 & 09/04/2014 & $35059.5952^{\prime}$ & 60 45.8666' & 660 & $06: 23$ & 0.0036 & 0.65 \\
\hline Furrow & 4 & 09/04/2014 & $36 \circ 00.4360^{\prime}$ & 60 44.2907' & 662 & $01: 45$ & 0.0004 & 0.65 \\
\hline US & 5 & 09/05/2014 & $36005.4462^{\prime}$ & $6032.4239^{\prime}$ & 224 & $01: 54$ & 0.0039 & 0.20 \\
\hline Furrow & 6 & $09 / 05 / 2014$ & $36001.1509^{\prime}$ & $6040.5630^{\prime}$ & 626 & $04: 58$ & 0.0024 & 0.60 \\
\hline CC & 7 & 09/06/2014 & 35 $43.9216^{\prime}$ & 6o 38.2539' & 593 & $03: 25$ & 0.0137 & 0.65 \\
\hline CC & 8 & 09/06/2014 & $35 \circ 45.2046^{\prime}$ & 6o 42.0749' & 691 & $04: 37$ & 0.0039 & 0.60 \\
\hline $\mathrm{CC}$ & 10 & 09/07/2014 & $35045.8414^{\prime}$ & 6o 41.4889' & 707 & $02: 11$ & 0.0011 & 0.75 \\
\hline Furrow & 11 & 09/07/2014 & $35 \circ 47.1166^{\prime}$ & 6o 39.9556' & 633 & $03: 21$ & 0.0012 & 0.85 \\
\hline Furrow & 12 & 09/08/2014 & $36003.1527^{\prime}$ & 7o 02.0464' & 798 & 03:30 & 0.0036 & 0.35 \\
\hline Furrow & 13 & 09/08/2014 & $35055.4302^{\prime}$ & 7ㅇ 10.0469' & 978 & $03: 52$ & 0.0016 & 0.15 \\
\hline $\mathrm{CC}$ & 14 & 09/09/2014 & $36016.2517^{\prime}$ & 7으 08.0895' & 911 & 03:34 & 0.0007 & 0.50 \\
\hline Furrow & 15 & 09/09/2014 & $36 \div 09.7459^{\prime}$ & $6056.8595^{\prime}$ & 742 & $04: 26$ & 0.0058 & 0.40 \\
\hline $\mathrm{CC}$ & 16 & 09/10/2014 & $36016.1242^{\prime}$ & 60 47.5995' & 664 & $03: 50$ & 0.0076 & 0.30 \\
\hline Canyon & 17 & 09/10/2014 & $36017.7340^{\prime}$ & 6o 46.7173' & 883 & $05: 24$ & 0.0285 & 0.25 \\
\hline Furrow & 18 & 09/11/2014 & $36906.1391^{\prime}$ & 70 14.8768' & 891 & $02: 59$ & 0.0140 & 0.35 \\
\hline Furrow & 19 & $09 / 11 / 2014$ & 360 11.5924' & 60 50.3949' & 638 & 02:01 & 0.0003 & 0.40 \\
\hline
\end{tabular}


Table 2. Abundance (items $/ \mathrm{km}^{2}$ ) of all types of litter per each morpho-sedimentary

499 domain.

500

\begin{tabular}{lcccc}
\hline \multicolumn{1}{c}{ Type of Litter } & $\begin{array}{c}\text { Contouritic } \\
\text { Furrow }\end{array}$ & $\begin{array}{c}\text { Contouritic } \\
\text { Channel }\end{array}$ & $\begin{array}{c}\text { Upper Open } \\
\text { Slope }\end{array}$ & $\begin{array}{c}\text { Upper slope } \\
\text { Canyon }\end{array}$ \\
\hline Plastic & 268.3 & 569.8 & 371.8 & 982.5 \\
Glass & 111.7 & 1169.2 & 38.5 & 35.1 \\
Metal & 285.6 & 519.9 & 166.7 & 1263.2 \\
Longline & 154.3 & 0 & 0 & 0 \\
Fishing Net & 216 & 181.8 & 0 & 0 \\
Ceramic & 204.3 & 0 & 115.4 & 0 \\
Total & 1240.2 & 2440.7 & 692.4 & 2280.8 \\
\hline
\end{tabular}

501

502 


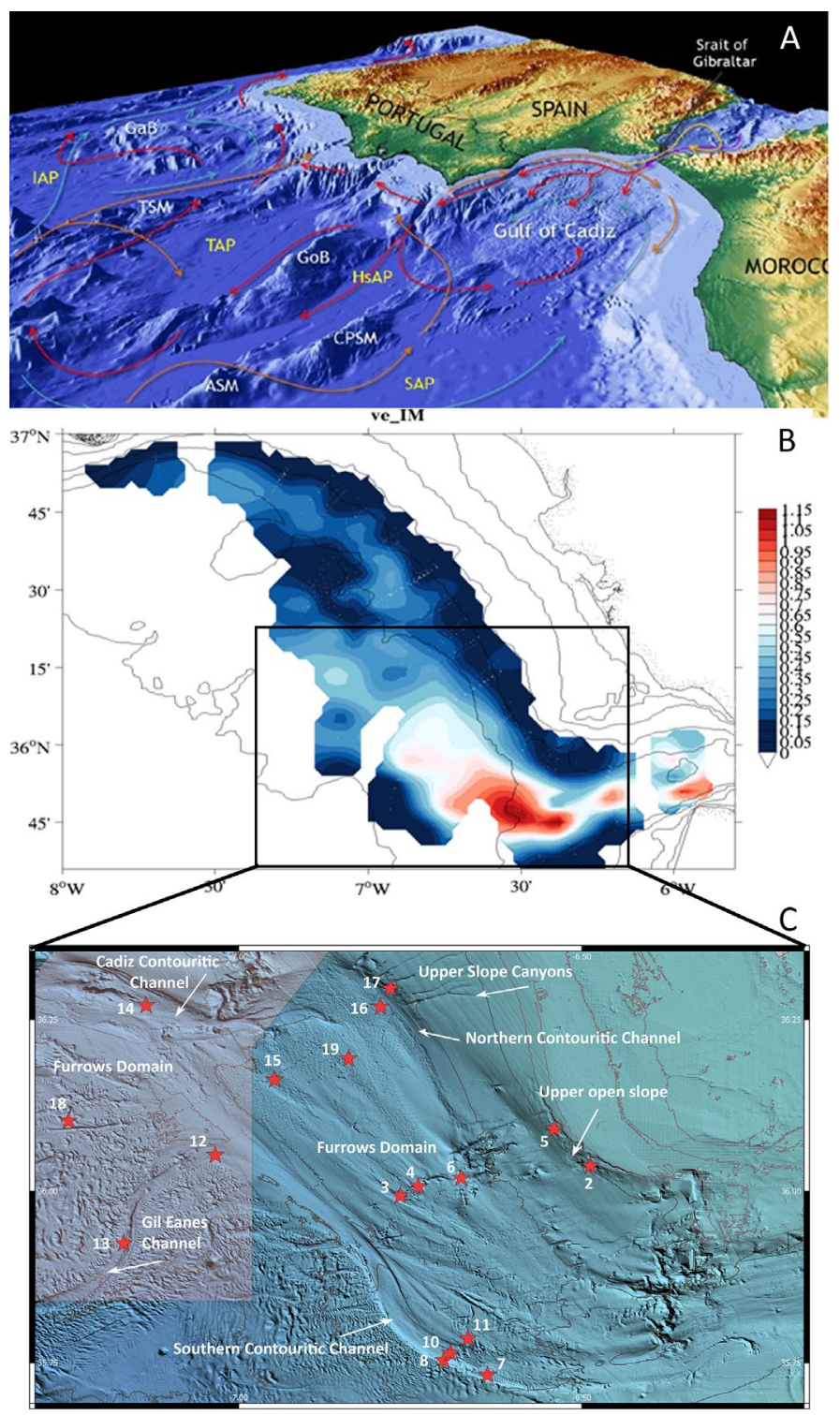

521 Fig. 1. A) Seabed morphology and oceanographic circulation model. Legend: orange 522 arrow: Atlantic Current; yellow arrow: Atlantic inflow Water; red arrow: 523 Mediterranean Outflow Water; blue arrow: North Atlantic Deep Water; purple: 524 Western Mediterranean Deep Water; ASM: Ampere Seamount; CPSM: Coral Patch 525 Seamount; GaB: Galicia Bank; GoB: Gorringe Bank; TSM: Tore Seamount; IAP: Iberia 526 Abyssal Plain; TAP: Tagus Abyssal Plain; HsAP: Horseshoe Abyssal Plain; SAP: Seine 527 Abyssal Plain (Image from https://joidesresolution.org/expedition/339). B) Near528 ground LADCP velocities (m/s) (form Sanchez-Leal et al., 2014). C) Bathymetric map 529 displaying the location of ROVs dives (red stars) indicated in relation to the main 530 depositional and erosive features. Compilation of bathymetry from (Zitellini et al., 
531 2009) and GEBCO, and also from Contouriber project (e.g., (Hernández-Molina et al.,

532 2014) (pink area: Site of Community Importance (Habitats Directive) Volcanes de fango 533 del Golfo de Cádiz).

534

535

536

537

538

539

540

541

542

543 

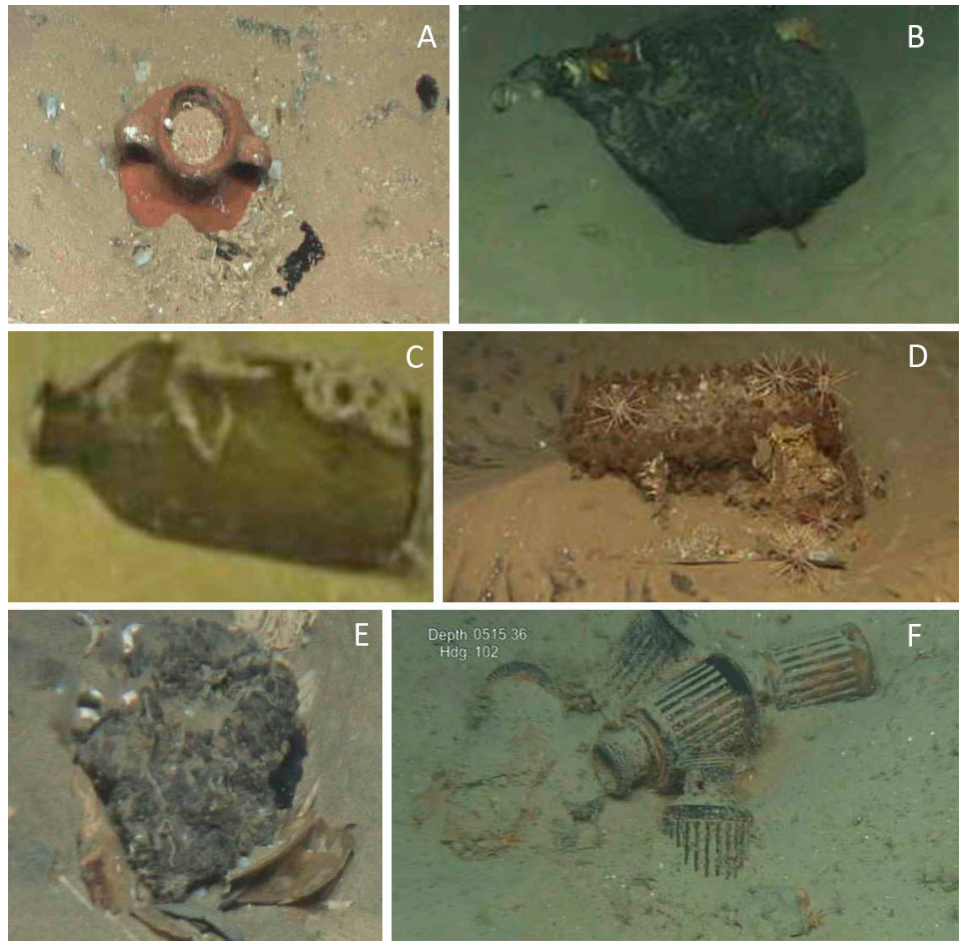

544

545 Fig. 2. Differed types of video-detected litter artifacts. A) Ceramic; B) Black plastic; C) 546 Cristal bottle; D) Metal tube; E) Clinker-like debris with plastic; F) Military artifacts.

547

548

549 


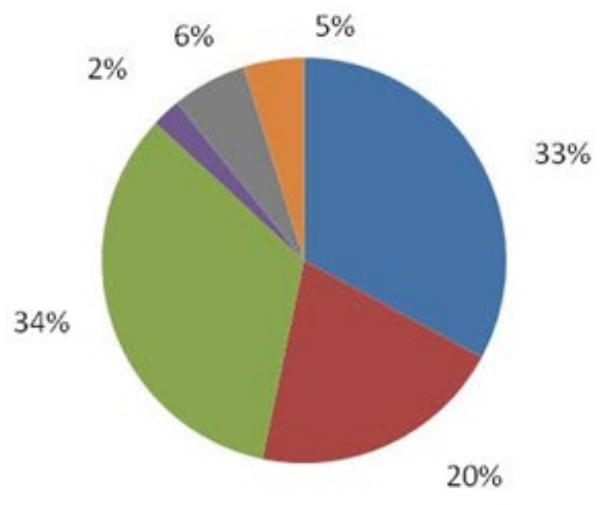

A

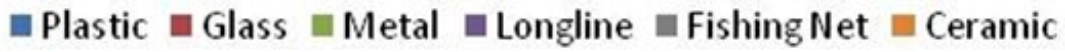

B

C
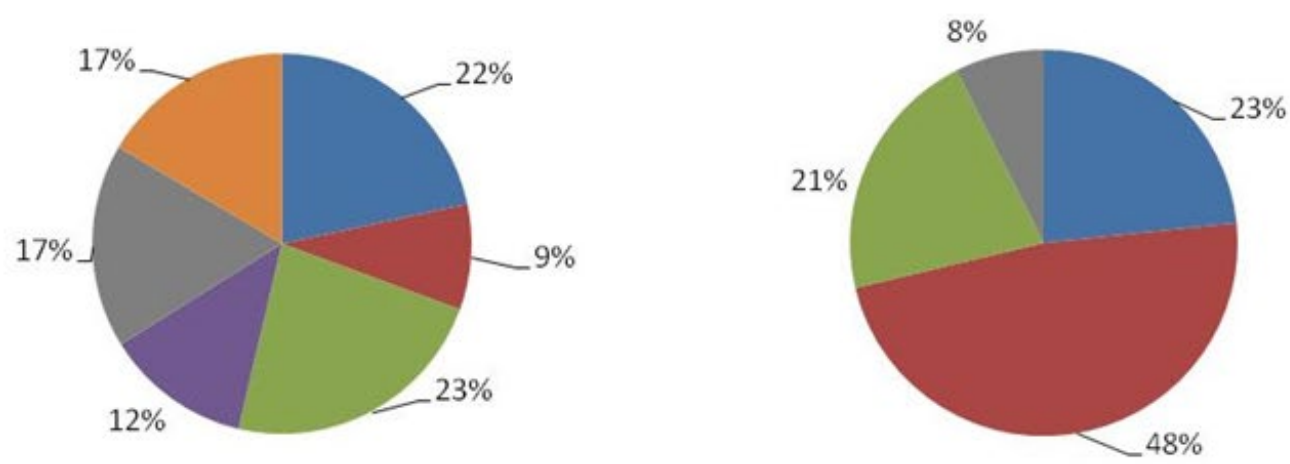

D

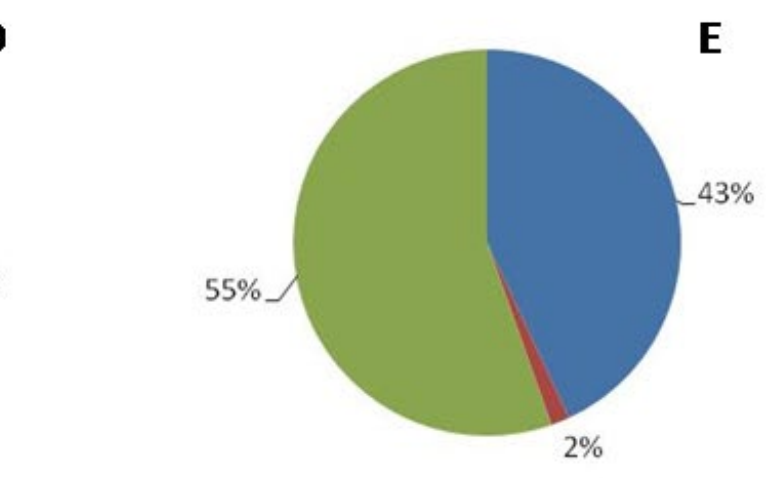

550

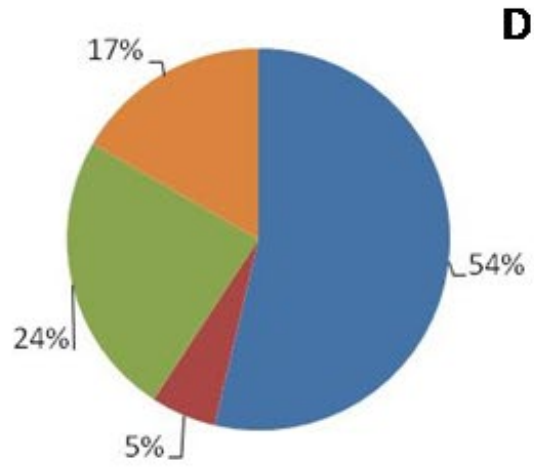

E

551 Fig. 3. Percentage of total litter observed in the morpho-sedimentary domains. A) Total

552 observations; B) Furrows domains; C) Contouritic channel domain; D) Upper Open

553 Slope domain; and E) Upper slope canyon domain. 

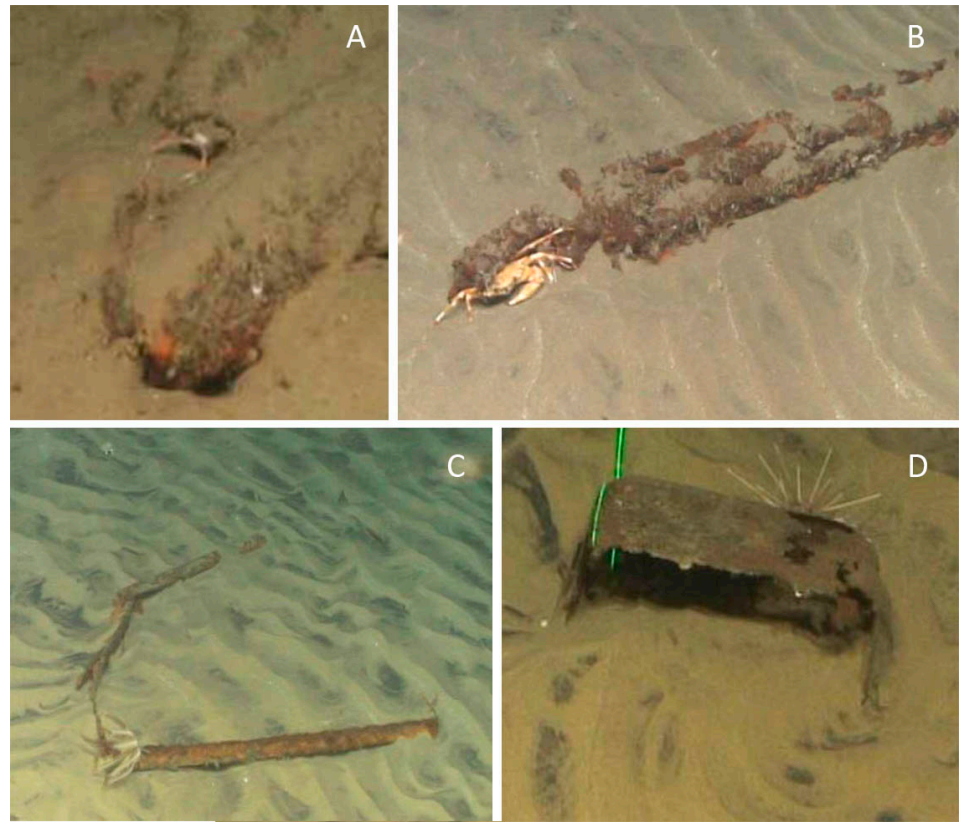

555

556 Fig. 4. Several species observed interacting with litter artefacts. A) Munida sp. hiding

557 under a metal projectile. B) The crab B. maravigna hiding by a metal artefact. C)

558 crinoid Leptometra celtica and unclassified Anthozoan in contact with a long piece of metal. D) Cidaris cidaris observed near litter artefacts.

560

561

562

563

564

565 

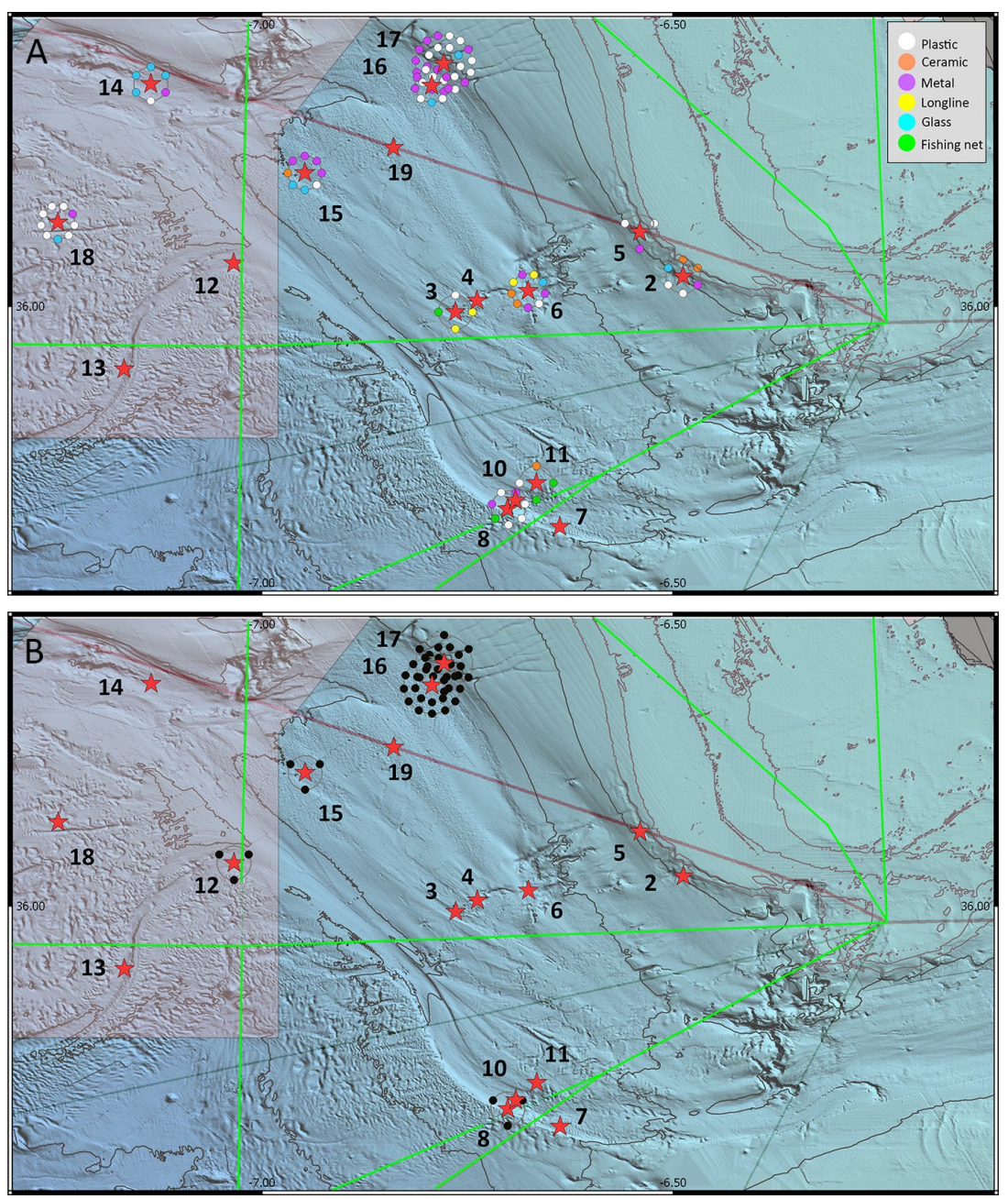

568

569 Fig. 5. Overlapping of A) litter and B) clinker-like debris distribution map with maritime

570 traffic data as straight lines (Junta de Andalucía, 2011). Dives numbers (red stars; see

571 also Figure 1) and retrieved types of litter are also indicated (pink area: Site of 572 Community Importance (Habitats Directive) Volcanes de fango del Golfo de Cádiz). 